Volume I Tahun 2021

November 2021
E-ISSN: 2808-5361

http://e-journal.fkmumj.ac.id/
Proceeding The First

Muhammadiyah

Internasional- Public Health

and Medicine Conference

\title{
DESCRIPTION OF KNOWLEDGE AND BEHAVIOR LEVELS ABOUT BREAST EXAMINATION (BEST SELF-EXAMINATION) IN ADOLESCENT WOMEN
}

\author{
${ }^{1}$ Haina Maulani, ${ }^{2}$ Hanna Maulida, ${ }^{3}$ Ismiatun Jariyah, ${ }^{4}$ Nabilla Putri Jullizir \\ Public Health Study Program, Muhammadiyah University of Jakarta \\ Jl. K.H. Ahmad Dahlan, Cireundeu, Ciputat, Jakarta Selatan 15419 \\ Email: hannamlda28@gmail.com
}

\begin{abstract}
Breast self-examination (BSE) is done by feeling and looking at the breast itself to see the possibility of physical changes in the breast. This process is carried out so that all changes that lead to more serious conditions can be detected early. Breasts will generally feel different during menstruation. Before and during this period, most women feel that their breasts are getting tighter and denser. Therefore, women need to do a breast self-examination (BSE) every 1 month, to find out whether there is a change in the shape of the breast from time to time. This study aims to determine the level of knowledge and behavior about breast self-examination (Aware) in young women. The research used is qualitative research using a descriptive observational study design, namely conducting in-depth interviews with 4 informants which are by the interview guidelines.

Based on the results of the study, 4 respondents had been interviewed according to the addresses of their respective researchers, respondents according to the characteristics of the study. And respondents have good enough knowledge about breast self-examination (BSE), respondents also behave to check their breasts regularly after menstruation.
\end{abstract}

Keywords: Breast Self-Examination (BSE), Adolescent girls, BSE knowledge 
Volume I Tahun 2021

November 2021
E-ISSN: 2808-5361

http://e-journal.fkmumj.ac.id/
Proceeding The First

Muhammadiyah

Internasional- Public Health

and Medicine Conference

\section{INTRODUCTION}

Adolescence is a developmental period during which individuals undergo changes from childhood to adulthood, usually between the ages of 13 and 20 years. Adolescents begin to develop abilities in the decision-making process, learn to understand things, receive various kinds of information, and understand cultural differences in society. In addition, the highest level of cognitive function makes adolescents willing to receive more detailed and diverse information about sexuality related to the stage of puberty they are going through. In adolescent girls, there are physical developments such as the development of menstruation, breast development, and ovulation which of course will be an interesting thing for young women to learn by looking for related information, especially if there are abnormal changes such as breast cancer (Berek et al., 2019).

Breast cancer is a major public health problem worldwide and is a very significant cause of morbidity and mortality because it is the second leading cause of death in women (Agustin et al., 2021). Breast cancer or mammary carcinoma is the growth of cells that cannot be controlled by the milkproducing glands (lobular), the gland ducts from the lobular to the nipple (ducts), and the supporting tissues of the breast that surround the lobular, ducts, blood vessels and lymph vessels, but do not. including skin. Breast cancer (carcinoma mammae) is a condition in which the cells of this disease have lost their normal control and mechanism, resulting in abnormal, rapid, and uncontrolled growth that occurs in breast tissue (Damayanti, 2017).

According to the WHO (World Health Organization) in 2018 showed that the number of breast cancer sufferers worldwide reached more than 2.1 million cases, there were $15 \%$ of deaths from 627 thousand women were caused by breast cancer. The WHO statement in the World Cancer Report 2020 states that in the next two decades the world will experience an increase in breast cancer cases, which is around $60 \%$ or one in six people die from cancer every year. WHO also states that there will be a significant increase in breast cancer cases, namely 1.7 million new cases every year (MANALU, 2019).

The highest cancer in Indonesia in women is breast cancer and cervical cancer. Based on data from Basic Health Research, cancer cases in Indonesia in 2018 were 1.8 per 100,000 population and ranked 8th in Southeast Asia. The highest cancer prevalence is in DI Yogyakarta Province at 4.86 per 1000 population (Arfan et al., 2020). As many as $70 \%$ of breast cancer cases are found in an advanced stage (Singam \& Wirakusuma, 2017). 
Volume I Tahun 2021

November 2021
E-ISSN: 2808-5361

http://e-journal.fkmumj.ac.id/
Proceeding The First

Muhammadiyah

Internasional-Public Health

and Medicine Conference

\section{METHODS}

The type of research used is qualitative research with a descriptive observational study design, namely conducting in-depth interviews using interview guidelines that aim to describe the level of knowledge and behavior about breast self-examination (BSE) in adolescent girls. This study uses a qualitative approach to describe the level of knowledge and behavior of breast examination (BSE) in adolescent girls.

The targets in this study were young women in the regions of each researcher and the time of the study was carried out in May-June 2021.

Sources of information or informants in this study were the closest people who were teenagers according to the research criteria. For the selection of informants by selecting certain samples are assessed according to the objectives or problems in the study and with the consideration that they are currently the most knowledgeable about the problems to be studied. Informants who will conduct in-depth interviews are 4 adolescent informants according to where the researcher lives. Informants were selected based on their capacity to explain the objectives of this study.

Table 1. Informants in-depth Interviews

\begin{tabular}{cccc}
\hline Informant's Initials & Age & Gender & Profession \\
\hline AS & 18 & $\mathrm{P}$ & Student \\
RAP & 20 & $\mathrm{P}$ & Student \\
YK & 20 & $\mathrm{P}$ & Student \\
AP & 20 & $\mathrm{P}$ & Student \\
\hline
\end{tabular}

There are two types of data sources used in this study, namely:

a. Primary data

Primary data were obtained from direct observations in the field with questions using previously prepared guidelines.

b. Secondary Data

Secondary data were obtained from journals related to this research as well as regulations related to this research.

Data validity was done by the triangulation method. This study uses in-depth interviews conducted with informants in the area of each researcher and uses data written in journals.

To maintain the validity of the data, to determine the validity of the data in this study, a triangulation method was used. Method triangulation was carried out by using in-depth interviews with predetermined informants and reviewing documents from the description of the level of knowledge and 
Volume I Tahun 2021

November 2021
E-ISSN: 2808-5361

http://e-journal.fkmumj.ac.id/
Proceeding The First

Muhammadiyah

Internasional-Public Health

and Medicine Conference

behavior about breast self-examination (BSE) in adolescent girls that had been made in previous studies. Researchers used this triangulation to ensure the accuracy of the informants collected.

In qualitative research, testing the validity and reliability is called checking the validity of the data. The validity of the data is an important part because it is needed to understand the level of trustworthiness of the research results. The formulation of the validity of the data has criteria for the degree of trust, transferability, dependence, and certainty. Of the four criteria, the qualitative approach has eight techniques in testing the data, namely participation counseling, the persistence of observation, triangulation, peer checking, adequacy of references, negative case studies, member checking, and detailed descriptions. In this study, researchers checked the validity of the data by using triangulation techniques.

Triangulation is an approach using multiple methods when collecting and analyzing data. Triangulation can be interpreted as a technique of checking the validity of data by using other things when checking or comparing data. Other things that are needed in the comparison of data are sources, methods, researchers, and theories. Triangulation can be divided into four types of techniques, namely source triangulation, method triangulation, theory triangulation, and researcher triangulation.

In this study, the technique used by the researcher is the triangulation method, namely by comparing information or data in different ways. Like research usually in qualitative research, the methods used by researchers in collecting data are interviews, observations, and surveys. To obtain the truth of credible information and a complete picture of certain information, researchers can use free interview methods and structured interviews. Or, the researcher uses interviews and observations or observations to check the truth. In addition, researchers can also use different informants to check the truth of the information (Hadi, 2017). Processing and analysis of qualitative data in this study were carried out in the following stages:

Transferring data in the form of records into written form completely without changing, adding, or subtracting the information contained in the recording. This data transcript listens to the recorded interview results carefully regarding the conversation between the interviewer and the interviewee.

This research was collected through in-depth interviews and document review and then analyzed descriptively so that conclusions were obtained from the data that had been processed by coding each respondent's answers. 


\section{RESULTS AND DISCUSSION}

Table 2. Results of Interview Data Analysis

\begin{tabular}{|c|c|c|c|c|c|c|}
\hline No. & $\begin{array}{c}\text { Topic } \\
\text { (Pertanyaan) }\end{array}$ & $\begin{array}{c}\text { Meaning Unit } \\
\text { (Jawaban } \\
\text { Informan) }\end{array}$ & Code & Sub Category & Category & Theme \\
\hline 1. & $\begin{array}{l}\text { How did } \\
\text { you do a } \\
\text { breast self- } \\
\text { examination } \\
\text { (BSE) the } \\
\text { first time? }\end{array}$ & $\begin{array}{l}\text { - Fingering } \\
\text { breasts }\end{array}$ & $\begin{array}{l}\text { To do } \\
\text { Movement }\end{array}$ & $\begin{array}{l}\text { BSE } \\
\text { Movement }\end{array}$ & $\begin{array}{l}\text { Healthy } \\
\text { activities }\end{array}$ & $\begin{array}{l}\text { Breast self- } \\
\text { examinatio } \\
\mathrm{n}(\mathrm{BSE})\end{array}$ \\
\hline 2. & $\begin{array}{l}\text { Do you do a } \\
\text { breast self- } \\
\text { examination } \\
\text { (BSE) } \\
\text { between the } \\
7 \text { th and } \\
\text { 10th day of } \\
\text { your period } \\
\text { each } \\
\text { month? }\end{array}$ & $\begin{array}{l}\text { - On-time } \\
\text { on the } \\
\text { 7th day } \\
\text { - } \quad \text { Not } \\
\text { doing } \\
\text { BSE on } \\
\text { the } 7 \text { th } \\
\text { and } 10 \text { th } \\
\text { days }\end{array}$ & $\begin{array}{ll}-\quad & \text { Routinel } \\
\text { y do } \\
\text { BSE } \\
\text { - } \quad \text { Not } \\
\text { Routinel } \\
\text { y do } \\
\text { BSE }\end{array}$ & $\begin{array}{l}\text { Regularity of } \\
\text { BSE } \\
\text { examinations }\end{array}$ & $\begin{array}{l}\text { BSE inspection } \\
\text { activities }\end{array}$ & $\begin{array}{l}\text { Routine } \\
\text { breast self- } \\
\text { examinatio } \\
\text { n (BSE) }\end{array}$ \\
\hline \multirow[t]{5}{*}{3.} & $\begin{array}{l}\text { Do you feel } \\
\text { any } \\
\text { strangeness } \\
\text { around your } \\
\text { breasts } \\
\text { when you } \\
\text { do a breast } \\
\text { self- } \\
\text { examination } \\
\text { (BSE)? }\end{array}$ & $\begin{array}{l}\text { - Do not feel } \\
\text { strange } \\
\text { during the } \\
\text { examination }\end{array}$ & $\begin{array}{l}\text { - No } \\
\text { abnormalitie } \\
\text { S }\end{array}$ & - No symptoms & $\begin{array}{l}\text { - Free from } \\
\text { disease }\end{array}$ & $\begin{array}{l}\text { Prevention } \\
\text { through } \\
\text { BSE early } \\
\text { on }\end{array}$ \\
\hline & $\begin{array}{l}\text { (If } \\
\text { yes....did } \\
\text { you get } \\
\text { treatment } \\
\text { right } \\
\text { away?/If } \\
\text { not....why } \\
\text { didn't you } \\
\text { get } \\
\text { treatment?) }\end{array}$ & - & - & - & - & - \\
\hline & $\begin{array}{l}\text { Where to go } \\
\text { for treatment? }\end{array}$ & - & - & - & - & - \\
\hline & $\begin{array}{l}\text { If treatment is } \\
\text { difficult to get } \\
\text { the medicine? }\end{array}$ & - & - & - & - & - \\
\hline & If you get the & - & - & - & - & - \\
\hline
\end{tabular}




\begin{tabular}{|c|c|c|c|c|c|c|}
\hline No. & $\begin{array}{c}\text { Topic } \\
\text { (Pertanyaan) }\end{array}$ & $\begin{array}{c}\text { Meaning Unit } \\
\text { (Jawaban } \\
\text { Informan) }\end{array}$ & Code & Sub Category & Category & Theme \\
\hline & $\begin{array}{l}\text { medicine, is it } \\
\text { difficult to } \\
\text { take the } \\
\text { medicine? }\end{array}$ & & & & & \\
\hline 4. & $\begin{array}{l}\text { Have you } \\
\text { noticed any } \\
\text { changes in } \\
\text { the shape, } \\
\text { size of your } \\
\text { breasts, skin } \\
\text { surface, and } \\
\text { nipples? }\end{array}$ & $\begin{array}{l}\text { - Pay } \\
\text { attention to } \\
\text { the area } \\
\text { around the } \\
\text { breast }\end{array}$ & $\begin{array}{l}\text { - There are a } \\
\text { change in } \\
\text { the shape, } \\
\text { size of the } \\
\text { breast, skin } \\
\text { surface, and } \\
\text { nipples }\end{array}$ & $\begin{array}{l}\text { - Pay } \\
\text { attention to } \\
\text { physical } \\
\text { form }\end{array}$ & $\begin{array}{l}\text { - Pay attention } \\
\text { to the area } \\
\text { around the } \\
\text { breast }\end{array}$ & $\begin{array}{r}\text { - Care for } \\
\text { yourself }\end{array}$ \\
\hline 5. & $\begin{array}{l}\text { When in } \\
\text { front of the } \\
\text { mirror, raise } \\
\text { your hand } \\
\text { and do the } \\
\text { examination } \\
\text { there is } \\
\text { redness or } \\
\text { swelling } \\
\text { around the } \\
\text { breast? }\end{array}$ & $\begin{array}{l}\text { No redness } \\
\text { on the breast }\end{array}$ & $\begin{array}{l}\text { - No } \\
\text { symptoms }\end{array}$ & - No changes & - Healthy & $\begin{array}{l}\text { Healthy } \\
\text { important }\end{array}$ \\
\hline 6. & $\begin{array}{l}\text { Please tell } \\
\text { me, are } \\
\text { there any } \\
\text { dietary rules } \\
\text { you got } \\
\text { from } \\
\text { sharing } \\
\text { information } \\
\text { resources } \\
\text { for breast } \\
\text { health? Or } \\
\text { is it the } \\
\text { same? }\end{array}$ & $\begin{array}{ll}\text { There } \\
\text { are } \\
\text { restricti } \\
\text { ons on } \\
\text { junk } \\
\text { food } \\
\text { There is } \\
\text { no taboo } \\
\text { on junk } \\
\text { food }\end{array}$ & $\begin{array}{l}\text { - Rules of } \\
\text { eating } \\
\text { patterns by } \\
\text { consuming } \\
\text { nutritious } \\
\text { food }\end{array}$ & $\begin{array}{l}\text { - History of } \\
\text { food } \\
\text { consumption }\end{array}$ & $\begin{array}{l}\text { - There are } \\
\text { dietary rules }\end{array}$ & $\begin{array}{l}\text { Diet plan } \\
\text { for health }\end{array}$ \\
\hline 7. & $\begin{array}{l}\text { Please tell } \\
\text { me how } \\
\text { your } \\
\text { worries and } \\
\text { concerns } \\
\text { are if you } \\
\text { experience } \\
\text { strange } \\
\text { things such } \\
\text { as lumps or } \\
\text { redness } \\
\text { around the }\end{array}$ & $\begin{array}{l}\text { - anxiety and } \\
\text { worry if you } \\
\text { experience } \\
\text { strange things }\end{array}$ & $\begin{array}{l}\text { - Self } \\
\text { restlessness }\end{array}$ & $\begin{array}{l}\text { - Panic about } \\
\text { the } \\
\text { strangeness } \\
\text { around the } \\
\text { breast }\end{array}$ & $\begin{array}{l}\text { - Worry about } \\
\text { the disease }\end{array}$ & $\begin{array}{l}\text { Treatment } \\
\text { of diseases } \\
\text { of the } \\
\text { breast }\end{array}$ \\
\hline
\end{tabular}


Volume I Tahun 2021

November 2021
E-ISSN: 2808-5361

http://e-journal.fkmumj.ac.id/
Proceeding The First

Muhammadiyah

Internasional-Public Health

and Medicine Conference

\begin{tabular}{|c|c|c|c|c|c|c|}
\hline No. & $\begin{array}{c}\text { Topic } \\
\text { (Pertanyaan) }\end{array}$ & $\begin{array}{c}\text { Meaning Unit } \\
\text { (Jawaban } \\
\text { Informan) }\end{array}$ & Code & Sub Category & Category & Theme \\
\hline & breasts? & & & & & \\
\hline 8. & $\begin{array}{l}\text { Do you do } \\
\text { breast } \\
\text { massage } \\
\text { movements } \\
\text { up and } \\
\text { down, } \\
\text { massaging } \\
\text { around the } \\
\text { breast in a } \\
\text { circle, and } \\
\text { pressing the } \\
\text { breast } \\
\text { towards the } \\
\text { nipple? }\end{array}$ & $\begin{array}{l}\text { - do breast } \\
\text { massage } \\
\text { movements }\end{array}$ & $\begin{array}{l}\text { - massaging } \\
\text { motion }\end{array}$ & - Activity & $\begin{array}{l}\text { - Massage } \\
\text { behavior }\end{array}$ & $\begin{array}{l}\text { Effectivene } \\
\text { ss of breast } \\
\text { massage } \\
\text { movement }\end{array}$ \\
\hline 9. & $\begin{array}{l}\text { Can a lump } \\
\text { around the } \\
\text { breast be } \\
\text { considered } \\
\text { breast } \\
\text { cancer? } \\
\end{array}$ & $\begin{array}{l}\text { - Can't be } \\
\text { said as } \\
\text { breast } \\
\text { cancer }\end{array}$ & - Knowledge & $\begin{array}{l}\text { - Breast } \\
\text { cancer views }\end{array}$ & Insight & $\begin{array}{l}\text { Breast } \\
\text { cancer } \\
\text { Information }\end{array}$ \\
\hline 10. & $\begin{array}{l}\text { What do } \\
\text { you know } \\
\text { about } \\
\text { benign } \\
\text { breast } \\
\text { tumors and } \\
\text { breast } \\
\text { cancer? Is it } \\
\text { the same? }\end{array}$ & $\begin{array}{l}\text { Difference } \\
\text { between } \\
\text { benign } \\
\text { breast } \\
\text { tumor and } \\
\text { breast } \\
\text { cancer }\end{array}$ & - knowledge & $\begin{array}{l}\text { - Breast cancer } \\
\text { views }\end{array}$ & - insights & $\begin{array}{l}\text { Breast } \\
\text { cancer } \\
\text { Information }\end{array}$ \\
\hline 11. & $\begin{array}{l}\text { What are } \\
\text { your } \\
\text { barriers to } \\
\text { doing BSE? }\end{array}$ & $\begin{array}{l}\text { There } \\
\text { are } \\
\text { obstacle } \\
\text { s to } \\
\text { doing } \\
\text { BSE } \\
\text { - There } \\
\text { are no } \\
\text { obstacle } \\
\text { s to } \\
\text { BSE } \\
\end{array}$ & $\begin{array}{l}\text { - Behavioral } \\
\text { barriers }\end{array}$ & - Obstacles & - Barriers to BSE & $\begin{array}{l}\text { Obstacles } \\
\text { in doing } \\
\text { BSE }\end{array}$ \\
\hline 12. & $\begin{array}{l}\text { What do } \\
\text { you think? } \\
\text { Is the BSE } \\
\text { examination } \\
\text { very helpful } \\
\text { in the early } \\
\text { detection of }\end{array}$ & $\begin{array}{l}\text { - Very } \\
\text { helpful for } \\
\text { early } \\
\text { detection of } \\
\text { breast } \\
\text { cancer }\end{array}$ & - Knowledge & $\begin{array}{l}\text { - Breast cancer } \\
\text { views }\end{array}$ & - Insights & $\begin{array}{l}\text { Breast } \\
\text { cancer } \\
\text { Information }\end{array}$ \\
\hline
\end{tabular}


Volume I Tahun 2021

November 2021
E-ISSN: 2808-5361

http://e-journal.fkmumj.ac.id/
Proceeding The First

Muhammadiyah

Internasional- Public Health

and Medicine Conference

\begin{tabular}{lllllll}
\hline No. & $\begin{array}{c}\text { Topic } \\
\text { (Pertanyaan) }\end{array}$ & $\begin{array}{c}\text { Meaning Unit } \\
\text { (Jawaban } \\
\text { Informan) }\end{array}$ & Code & Sub Category & Category & Theme \\
\hline $\begin{array}{l}\text { breast } \\
\text { cancer? }\end{array}$ & & & & \\
\hline
\end{tabular}

Based on the results of the study, 4 respondents had been interviewed according to the addresses of their respective researchers, respondents according to the characteristics of the study. And respondents have good enough knowledge about breast self-examination (BSE), respondents also behave to check their breasts regularly after menstruation.

Knowledge is the respondent's or student's understanding of how to do BSE including understanding, purpose, time, and how to do BSE. Karayurt, Ozmen, \& Cetinkaya, (2008) stated that a good knowledge of BSE procedures is very important for young women because knowing about BSE procedures is one of the reasons why young women apply BSE as a routine habit in early detection of breast cancer. According to the results of the interviews, respondents had quite extensive knowledge about BSE because this information was not so foreign to them, almost all of the respondents asked during the interview already knew and understood.

This is in line with the theory (Notoatmodjo, 2003) explaining that knowledge is the result of "knowing" and this occurs after people sense a certain object. Sensing occurs through the five human senses, namely: the senses of sight, hearing, smell, taste, and touch. Most of the human knowledge is obtained through education, other people's experiences, mass media, and the environment. This is also supported by factors that influence one's knowledge. One of them is the educational factor that can affect a person, including a person's behavior regarding the pattern of life. In general, the higher a person's education, the easier it is to receive information and the better his knowledge (Soekanto, 2010).

The ability is being able to practice BSE steps which consist of 4 aspects, namely in a standing position in front of a mirror with hands beside the body, hands placed on the waist, and a lying position with a pillow under the shoulders and circular movements using 3 fingers.

Based on the results of interviews about the behavior of breast self-examination in adolescent girls, it shows that most of them carry out routine breast self-examination as many as 4 respondents and almost all of them carry out breast self-examination behavior. Respondents who rated doing breast selfexamination regularly rated the benefits of breast self-examination very high. According to research by Suryaningsih (2009), BSE is one of the easier and more efficient ways to detect breast abnormalities by yourself. By the theoretical review, it is stated that the high mortality rate due to breast cancer is caused 
Volume I Tahun 2021

November 2021
E-ISSN: 2808-5361

http://e-journal.fkmumj.ac.id/
Proceeding The First

Muhammadiyah

Internasional-Public Health

and Medicine Conference

by several factors, including patients who do not know and do not understand breast cancer, pay less attention to breast cancer, are afraid of surgery, and are lazy and embarrassed to show breasts.

In the results of the study, it was explained that the respondents did routine BSE according to the time, although some respondents felt they forgot to do BSE on time. BSE should be done every time after menstruation, which is the 7th to 10th day from the first day of menstruation because at this time the hormonal influence of estrogen and progesterone is very low and the breast gland tissue at that time does not swell so it is easier to feel for tumors or abnormalities in the breast. (Manuaba, 2010).

The researcher realizes that this research still has limitations. Based on the researcher's direct experience in the research process, there are several limitations experienced and can be several factors that can be given more attention to future researchers in further perfecting their research because this research itself certainly has shortcomings that need to be improved continuously in research. -Future research. Some of the limitations in this study are that in the process of collecting data, the information provided by respondents through questionnaires sometimes does not show the respondents' actual opinions, this happens because sometimes there are differences in thoughts, assumptions, and different understandings of each respondent, as well as other factors such as honesty in filling opinions respondents in the questionnaire.

In the perspective of Islam, learning is an obligation for every believer to acquire knowledge to improve the degree of their lives. Health in Islam is an important matter, it is a great blessing for which every servant should be grateful. Regarding the importance of health the Prophet sallallaahu 'alaihi wa sallam said:

نعمتان مغبون فيهما كثير من الناس الصحة و الفراغ

"Two pleasures that are often overlooked by most people are health and leisure." (Narrated by AlBukhari: 6412, at-Tirmidhi: 2304, Ibn Majah: 4170)

Ibn Battal explained that the meaning of this hadith is that a person is not said to have free time until he also has a healthy body. Whoever has this (free time and a healthy body) should be enthusiastic so that he does not be deceived by leaving gratitude to Allah for all the blessings He has given. Including gratitude to Allah is to carry out all His commands and stay away from all His prohibitions. Whoever is not grateful like that is a deceived person. (Fathul Bari bi Syarhi Sahihil Bukhari: 14/183-184).

Ibnul Jauzi said that sometimes a person has a healthy body, but he does not have free time because he is busy with his livelihood. Sometimes a person has free time but his body is not healthy. If these two blessings (free time and a healthy body) are owned by someone, then laziness dominates him to 
Volume I Tahun 2021

November 2021
E-ISSN: 2808-5361

http://e-journal.fkmumj.ac.id/
Proceeding The First

Muhammadiyah

Internasional-Public Health

and Medicine Conference

do obedience to Allah; then he is the one who is deceived. (Fathul Bari bi Syarhi Sahihil Bukhari: 14/184).

\section{CONCLUSIONS AND SUGGESTIONS}

Based on the results and discussion of the research, it can be concluded that

1. Based on the results of interviews that respondents know breast self-examination (BSE)

2. Based on the results of interviews that respondents routinely perform breast self-examination (BSE) after menstruation.

For the health sector, it is important to increase health promotion about education for young women to improve health status and provide counseling about breast cancer so that young women can detect disease early.

\section{REFERENCES}

Afianty, S. D., Handayani, S., \& Alibbirwin. (2019). Determinan Perilaku Remaja Putri Melakukan SADARI dalam Upaya Deteksi Dini Kanker Payudara. Photon: Jurnal Sain Dan Kesehatan, 10(1), 75-79. https://doi.org/10.37859/jp.v10i1.1384

Arafah, A. B. R., \& Notobroto, H. B. (2018). Faktor Yang Berhubungan Dengan Perilaku Ibu Rumah Tangga Melakukan Pemeriksaan Payudara Sendiri (Sadari). The Indonesian Journal of Public Health, 12(2), 143. https://doi.org/10.20473/ijph.v12i2.2017.143-153

Karayurt, O., Ozmen, D., \& Cetinkaya, A. cakmakci. (2008). Awareness of breast cancer risk factors and practice of breast self-examination among high school students in Turkey. BMC Public Health, 8(1), 359. https://doi.org/10.1186/1471-2458-8-359

Nugraheni, A. (2010). Hubungan tingkat pengetahuan tentang sadari dengan perilaku sadari sebagai deteksi dini kanker payudara pada mahasiswi DIV kebidanan FK UNS. Universitas Sebelas Maret.

Schiavo. (2014). Gambaran Tingkat Pengetahuan Remaja Tentang Pemeriksaan SADARI. 10-34.

Wiwi, A. (2015). Hubungan Tingkat Pengetahuan dengan Sikap Masyarakat Tentang Skistosomiasis di Kecamatan Lindu Kabupaten Sigi Sulawesi Tengah Tahun 2015. Ilmu Kedokteran, 53(9), 16891699.

Wulandari, A. (1369). Hubungan Tingkat Pengetahuan dan Perilaku tentang Pemeriksaan SADARI. 157.

Agustin, I., Kumalasari, I., \& Jaya, H. (2021). Pelatihan Pemeriksaan Payudara Sendiri (Sadari) Pada Siswi Sma Bina Lestari Kecamatan Gandus Sebagai Upaya Pencegahan Kanker Payudara. Abdi 
Volume I Tahun 2021

November 2021
E-ISSN: 2808-5361 http://e-journal.fkmumj.ac.id/
Proceeding The First

Muhammadiyah

Internasional- Public Health

and Medicine Conference

Dosen : Jurnal Pengabdian Pada Masyarakat, 5(1), 72. https://doi.org/10.32832/abdidos.v5i1.825

Arfan, I., Alamsyah, D., \& Utami, T. (2020). Gambaran Pemeriksaan Payudara Sendiri (SADARI) Pesantren Putri. 7(2), 16-25.

Berek, P. A. L., Niron, C. L. A., Riwoerohi, E. D. F., \& Fouk, M. F. W. A. (2019). Gambaran Tingkat Pengetahuan Remaja Putri Tentang Pemeriksaan Payudara Sendiri Di Sma Negeri 1 Atambua. Jurnal Kebidanan, 8(1), 16-23. https://doi.org/10.35890/jkdh.v8i1.110

Damayanti, R. (2017). Pengaruh Pelaksanaan Pemeriksaan Payudara Sendiri (SADARI) Terhadap Pengetahuan dan Kemampuan Siswi dalam Upaya Deteksi Dini Kanker Payudara di SMP Negeri 1 Sibulue Kabupaten Bone. Journal of Chemical Information and Modeling, 53(9), 1689-1699. http://digilib.unhas.ac.id/uploaded_files/temporary/DigitalCollection/YmY0MTQ1YjdkZDNhM2M 3ZDViMDUwYWQwYjM4ZmVjN2E0Zjg0OWM0Mg==.pdf

MANALU, Y. L. S. (2019). FAKTOR YANG MEMENGARUHI PEMANFAATAN DETEKSI DINI KANKER PAYUDARA DENGAN METODE CBE DI PUSKESMAS BROMO MEDAN. FaktorFaktor Yang Berhubungan Dengan Gejala Gangguan Kelelahan Mata Pada Supir Bus Antar Lintas Sumatera (ALS).

Singam, K. K., \& Wirakusuma, I. B. (2017). Gambaran tingkat pengetahuan dan perilaku tentang pemeriksaan payudara sendiri ( SADARI ) pada remaja putri di wilayah kerja UPT Puskesmas Blahbatuh II Gianyar Bali Indonesia. 8(3), 184-188. https://doi.org/10.1556/ism.v8i3.135 
Volume I Tahun 2021

November 2021
Proceeding The First Muhammadiyah

Internasional- Public Health and Medicine Conference http://e-journal.fkmumj.ac.id/

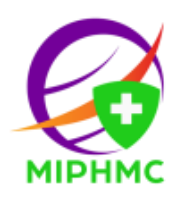

